\title{
An Economic Appraisal of Sustained Yield Forest Management
}

\author{
Abstract of a U.B.C. Ph.D. thesis by David Haley
}

Sustained yield forest management has been widely accepted as a major objective of forestry. It implies continuous production of forest crops with the aim of achieving, at the earliest practicable time, an approximate balance between net growth and harvest, either by annual or somewhat longer periods. The concept, introduced to North America by European foresters at the end of the 19th century, has become an important component of public policy for forestry and conservation.

History of sustained yield forest management, its role in conservation philosophy, and its economic advantages and disadvantages, as well as alternatives, are discussed. Evolution of sustained yield management and its application in British Columbia are described.

Many advantages have been claimed for sustained yield forest management as an alternative to unregulated liquidation of resources. Yet preservation of forests for the benefit of future generations, amelioration of uncertainty in forestry enterprises, protection of social values, stabilization of communities, and provision of regular incomes cannot, themselves, justify unconditional acceptance of sustained yield. Many of the benefits claimed for sustained yield are not dependent on the production of equal annual, or periodic, harvests but are the result of continuous forest production.

Sustained yield forest management emphasizes stability and continuity of production but neglects economic values of the resource. It may even retard economic growth and development. By using physical rather than economic criteria to set goals for forest management, sustained yield often causes the net present worth of the forest resource to fall short of its maximum potential value. Although sustained yield policy aims at stability, the inability of entrepreneurs to respond to cyclical changes in economic activity may actually lead to instability in stumpage prices and forest revenues.

The rational forest owner should only practise sustained yield forest management if it will achieve his objectives in the most efficient manner. Forest owners should always consider alternatives to sustained yield. Benefits must be analysed in relation to costs. Forest management planning also can be improved by linear programming and decision theory techniques as illustrated herein.

It is suggested that in British Columbia sustained yield forest management has become so firmly established that alternative policies are seldom considered. Rigid application of sustained yield principles forms an effective barrier to maximization of the social value of the Provincial forest resource. Opportunities for expansion of lumber and plywood industries are being curtailed, and inadequate attention has been given to planning the transition from old growth to second growth stands of Douglas fir. Despite its emphasis on "perpetual yields of wood of commercially usable quality from regional areas in yearly or periodic quantities of equal or increasing volume", forest management in British Columbia has neglected urgent needs for improved reforestation. 
After a thorough examination of its implications for British Columbia, it is concluded that sustained yield must be rejected as a universal goal of forest management. Sustained yield forest management should always be compared to other alternatives and be fully justified on economic and social grounds before it is accepted.

Product yield and value, financial rotations and biological relationships of good site Douglas fir.

Abstract of a U.B.C. M.F. thesis by James Dobie

The practice of sustained-yield forest management requires the formulation of management plans designed to ensure the economic efficiency of the forest enterprise. Consequently a knowledge of the volume and value of timber in forest stands is of the utmost importance to foresters engaged in sustained-yield management.

In this thesis an analysis of the quantity and value of the product yield from four natural stands of Douglas fir (Pseudotsuga menziesii (Mirb.) Franco) in British Columbia has been made. Average stand ages were 63, 86, 106 and 145 years with heights at 100 years of $160,165,175$ and 165 feet, respectively. Logging and milling costs for what is regarded as typical coastal British Columbia operations were derived from the literature and from local sources. Lumber yields and values presented were obtained from the results of four mill studies of sample logs from the above stands. Value and volume of plywood and piling products obtainable were ascertained from the literature and from local sources.

Linear progtamming techniques were used to determine the optimum jointproduct yield from each of the stands. Financial rotations at two levels of establishment costs, and three interest rates, were examined and mathematical models of the relationship between tree value, tree volume and biological variables are presented.

It was found that the net value per cubic foot of tree increased with tree size because of reduced handling costs per unit volume and better quality yield in the larger trees. At the level of costs and values used, and within limits of grade specifications, it is more profitable to produce piling from small trees, and plywood from large trees, rather than lumber. The linear programming solution to optimum product yield indicated that optimum conversion return for all stands was 5 cents per cubic foot greater than the lumber conversion return.

Financial rotations, at 3 per cent compound interest on establishment costs and on the value of the growing stock, are between 60 and 70 years for these sites. At 65 years the margin for profit and risk in these stands varied from $\$ 1400$ to $\$ 2000$ per acre, increasing with degree of stocking. An increase in establishment costs did not affect the rotation age but reduced the net value per acre of the stand. Increasing the interest rate reduced both the rotation age and the net value per acre of the stand.

Many biological variables were found to be significantly correlated with tree value and volume. However, regression models using only two or three variables were statistically as good as, and, from a practical point of view, 